\title{
Fermented dairy products based on ovine cheese whey
}

\author{
C. D. Pereira ${ }^{1}$ - M. Henriques ${ }^{1}$ - D. Gomes ${ }^{1} \cdot$ R. Gouveia $^{1}$ • A. Gomez-Zavaglia ${ }^{2}$ \\ G. de Antoni ${ }^{2,3}$
}

Revised: 23 February 2015 / Accepted: 22 April 2015

(C) Association of Food Scientists \& Technologists (India) 2015

\begin{abstract}
This work presents an alternative solution for ovine whey components recovery in medium/small cheese plants that predominate in the rural areas of Southern European countries, which are specialized in the production of protected designation of origin (PDO) cheeses. These plants lack the capacity to concentrate and dry whey, and although a significant amount of this by-product is used in the manufacture of whey cheeses, in several cases it is used as animal feed or simply discarded. As an alternative to these practices, we propose the production of liquid whey protein concentrates (LWPC) by means of ultrafiltration (UF) followed by thermal denaturation and homogenization and their utilization in the production of fermented products based on kefir grains and/or commercial probiotic bacteria. Two types of fermented products were prepared: one in a liquid form (low protein and fat contents) and other in a gel form (high protein and fat contents). The microbiological, physicochemical (gross composition, $\mathrm{pH}$, titratable acidity) and rheological properties of such products were assessed and compared during fermentation and at the 7th, 14th and 21st days of refrigerated storage. The fermented products presented adequate amounts of lactococci, lactobacilli ( $>7 \log 10$ CFUmL-1) and yeasts $(>6$ Log10 CFUmL-1). The rheological properties of liquid
\end{abstract}

C. D. Pereira

cpereira@esac.pt

1 IPC/ESAC/CERNAS, Polytechnic Institute of Coimbra, College of Agriculture, Coimbra, Portugal

2 Center for Research and Development in Food Cryotechnology, CCT-CONICET, La Plata RA-1900, Argentina

3 Laboratorio de Microbiología, Departamento de Ciencias Biológicas, Facultad de Ciencias Exactas, Universidad Nacional de La Plata, La Plata, Argentina products were stable during the 21 days of refrigerated storage. However, gel type products showed variations in viscosity after 14 days, in the cases in which kefir grains were present. Although further work is needed in order to optimize the formulations regarding to the improvement of their sensory properties, it was concluded that this approach allows for the production of innovative fermented dairy products.

Keywords Ovine $\cdot$ Whey $\cdot$ Ultrafiltration $\cdot$ Kefir $\cdot$ Probiotics

\section{Introduction}

Apart from the type of coagulation, whey composition primarily depends on milk origin (e.g., bovine, ovine or caprine), although seasonal cycles of lactation or feed changes may also account for some variations. The proximate composition of whey on a dry weight basis is lactose (65-75\%), nitrogenous compounds (proteins, peptides and amino acids) $8-11 \%$, fat (2-8\%), and minerals (9-13\%). Due to the composition of ovine milk, ovine whey presents significantly higher levels of total solids, lipids and especially proteins than bovine whey, which may render it more attractive for valorization (Pintado et al. 2001; Henriques et al. 2011).

Nowadays, whey is a valuable product both due to its components and the functional properties it can impart to food. Whey proteins are well-established as food ingredients, and applications have been found across a wide range of food products. Their nutritional and functional properties have been extensively reviewed and reported in the literature (Smithers 2008; Díaz et al. 2009). While the functionality of dehydrated whey protein products (e.g., WP, WPC or WPI) has been subject to several studies, little attention has been given to the functional properties of liquid whey protein concentrates 
(LWPC) produced by ultrafiltration (UF) and to their use in dairy products manufacture.

Recently, the applications of $\beta \mathrm{Lg}$ and WPI aggregates in cold-set gels, foams and emulsions, encapsulation and films/ coatings have been reviewed (Nicolai et al. 2011). Novel products, such as microparticulated whey proteins (MWP), (Torres et al. 2012) or polymerized whey proteins (PWP), (Wang et al. 2012) have been extensively evaluated as fat replacers in cheese or yoghurts (Sandoval-Castilla et al. 2004; Chung et al. 2013; Di Cagno et al. 2014), and their use is expected to rise.

In Portugal, sheep's milk represents $4 \%$ of the total milk production and is almost exclusively used for cheese production. Compared to the $1 \%$ production of sheep's milk worldwide (Gerosa and Skoet 2012), the importance of sheep's milk in the national context is obvious. Micro and small industries predominate, and their area of business is the niche market for protected designation of origin (PDO) cheeses and whey cheeses (Requeijão). However, if the annual production of Requeijão is taken into account, it can be concluded that a significant amount of whey is not processed. According to the producers, the high energy input in the production of Requeijão and its short shelf life (less than 7 days) are negative factors affecting the production/commercialization cycle. Moreover, the production of Requeijão is also discouraged by its low yield (app. $6 \% w / v$ ) (Pintado et al. 2001). Hence, producers are seeking to introduce new and more attractive products based on ovine/caprine whey. Recently, some efforts have been made to incorporate probiotic cultures in Requeijão, with the aim of increasing its nutritional value and to improve its sensory properties (Madureira et al. 2005, 2011, 2015). According to these authors, whey cheese is a good vehicle to deliver probiotic bacteria into the gastrointestinal tract. Moreover, taste and aroma in whey cheeses containing probiotic bacteria were considered better when compared to whey cheeses without probiotic bacteria.

The incorporation of liquid whey protein concentrates (LWPC) obtained by ultrafiltration in fresh cheese and set yoghurt was formerly proposed (Henriques et al. 2011, 2013) as a solution to the immediate reutilization of whey without the need for expensive processing steps (e.g., evaporation and drying).

Commonly, the use of whey proteins in the production of yoghurt includes whey powder (WP), whey protein concentrates (WPC) and microparticulated whey proteins (MWP) (Antunes et al. 2005; Amatayakul et al. 2006; Sodini et al. 2005; Sodini et al. 2006; Torres et al. 2011). However, some papers report the use of whey, whey permeate or deproteinized whey from whey cheese manufacture as ingredients in fermented products based on kefir grains (Athanasiadis et al. 2004; Abraham et al. 2011; Magalhães et al. 2011) or containing lactic acid bacteria (Pescuma et al. 2010).
The present approach focuses on using LWPC as the main ingredient in the production of gel- and liquid-type fermented products based on: (a) well-characterized kefir grains (Londero et al. 2012) containing microorganisms active against pathogenic bacteria (Golowczyc et al. 2007) or parasites (Franco et al. 2013); (b) a commercial mix of probiotic bacteria; and (c) a mixture of (a) and (b).

\section{Materials and methods}

\section{Production of LWPC}

Ovine cheese whey was obtained after raw milk cheese production and transported to the pilot plant of Escola Superior Agrária de Coimbra (ESAC, Portugal). The production of LWPC consisted in whey concentration at $45-50{ }^{\circ} \mathrm{C}$ in a batch ultrafiltration pilot plant, using an organic membrane DSS ${ }^{\mathrm{TM}}$ with a $10 \mathrm{kDa}$ cutoff. The target volumetric concentration factor (VCF) was 15-20. The UF concentrate was used as the substrate for gel-type fermented products. For liquid-type fermented products, concentrate composition was modified by decreaming in a Westfalia ${ }^{\mathrm{TM}}$ separator type $\mathrm{ADB}$, followed by dilution with UF permeate to achieve the desired levels of total solids and fat. Both base materials were then submitted to thermal treatment in batch conditions $\left(90^{\circ} \mathrm{C} / 5 \mathrm{~min}\right)$ to denature whey proteins and subsequently homogenized at $10 \mathrm{MPa}$ using a homogenizer Rannie ${ }^{\mathrm{TM}}$ model Bluetop to achieve a whey protein aggregate particle diameter lower than $10 \mu \mathrm{m}$. Homogenization is essential to eliminate graininess and increase the smoothness of the LWPC.

\section{Production of fermented products}

Two formulations were produced: a liquid-type product with a medium level of solids (app. $20 \% \mathrm{w} / \mathrm{w}$ ) and a gel-type product with a high level of solids (app. $35 \% w / w$ ). The fat content was adjusted to $1.5 \%$ in medium solids products and to $6.5 \%$ in high solids products. Fruit pulp $(10 \% w / v)$, sucrose $(5 \%$ $w / v)$ and flavoring (500 ppm) were added to the formulations and the mixtures were allowed to reach $25{ }^{\circ} \mathrm{C}$ before adding the inoculum.

Three types of fermented products per each formulation were produced: (a) the first based on kefir grains CIDCA AGK1 (Abraham et al. 2011) (2.5\%w/v); (b) the second based on a commercial mix of probiotic bacteria $\left(\mathrm{Sacco}^{\mathrm{TM}}\right.$, Lyofast ACR) $(0.3 \% w / v)$; and the third based on a 1:1 mixture of (a) and (b). Kefir grains used as inocula (stored at $-20^{\circ} \mathrm{C}$ ) were reactivated in milk at $25^{\circ} \mathrm{C}$ for $24 \mathrm{~h}$. All the inoculated LWPC were incubated at $25^{\circ} \mathrm{C}$ until the target $\mathrm{pH}$ (4.7) was reached, after which the kefir grains were removed. The obtained products were stored at $5{ }^{\circ} \mathrm{C}$ for 21 days. 


\section{Physicochemical analyses}

Product physicochemical composition ( $\mathrm{pH}$, titratable acidity (TA), total solids (TS), ash, fat and protein) was evaluated using the Portuguese Standards Methods (IPQ 1990) and the Official Analytical Methods (AOAC 1997). Each product sample was collected following the Portuguese standard procedure for dairy products (NP4146 1991).

Rheological properties were evaluated in a controlledstress rheometer (Rheostress 1 , ThermoHaake ${ }^{\mathrm{TM}}$ ) in oscillatory mode. The measuring system consisted of a cone and plate geometry, C60/Ti - $0.052 \mathrm{~mm}$ (35 mm diameter and $1^{\circ}$ angle). Stress sweep tests were conducted at $1 \mathrm{~Hz}$ to investigate the rheological linear viscoelastic behavior of gels. The elastic modulus (G') and viscous modulus (G'), complex viscosity $\left(\eta^{*}\right)$ of products were evaluated in the range of $0.3-6.5 \mathrm{rad} / \mathrm{s}$ at $3 \mathrm{~Pa}$.

\section{Microbiological analyses}

Viable microorganisms were enumerated immediately after inoculation $(0 \mathrm{~h})$, during fermentation $(12,18$ and $24 \mathrm{~h})$ and during storage at $5{ }^{\circ} \mathrm{C}$ for 14 days. Presumptive lactococci and lactobacilli were aerobically plate counted at $37^{\circ} \mathrm{C}$ for $48 \mathrm{~h}$ on M17 agar BK 088 and on MRS agar BK089 (Biokar Diagnostics, France), respectively. Yeasts were enumerated on Rose Bengal chloramphenicol agar BK 151 (Biokar Diagnostics, France) at $25^{\circ} \mathrm{C}$ after $72 \mathrm{~h}$.

\section{Sensorial analyses}

Consumer's preference tests were performed with an untrained panel of 30 persons. Products were tested at the 14th day of storage and panelists were asked to grade the different products in a scale from 1 (dislike a lot) to 5 (like a lot).

\section{Statistical analyses}

Analysis of variance (ANOVA) for the different assays was carried out using the statistical program Statistica 8 Software (Statsoft Inc. USA). Comparison of means was performed by the Tukey method, and if $P<0.05$ then the difference was considered statistically significant.

\section{Results and discussion}

\section{Physicochemical profiles}

Figure 1 displays the gross chemical composition of fermented products. A large difference is clear between the average protein content in gel-type products $(16.15 \pm 0.28 \%$ $w / w)$ and in liquid-type products $(5.45 \pm 0.21 \% w / w)$. Together with a higher level of fat in gel-type products (6.61 $\pm 0.13 \% w / w$ compared to $1.43 \pm 0.07 \% w / w)$, this accounts for the large difference between both product types, chiefly in their rheological properties.

Figures 2 and 3 display the evolution of $\mathrm{pH}$ and titratable acidity during the fermentation period and over storage at $5{ }^{\circ} \mathrm{C}$. Liquid products attained the target $\mathrm{pH}$ after $12-18 \mathrm{~h}$ of fermentation, whereas solid products only reached the target pH after 24 h. Significant differences were observed in the titratable acidity of the products with a medium and high level of solids. The concentration of lactic acid in products with a high level of solids was almost twice that of products with a low level of solids. However, the $\mathrm{pH}$ remained higher in geltype products. This can be attributed to the buffer activity of proteins in high solids products. In both formulations, the amount of lactic acid only increased $0.02 \%$ during the fermentation period. High acidity in formulations before fermentation results from the original acidity of whey, which increased during the production of LWPC. Immediate
Fig. 1 Gross chemical composition of: a liquid-type products fermented by kefir grains (K1), commercial mix of probiotic $(\mathrm{P} 1)$ and kefir grains + commercial mix of probiotic $(\mathrm{K}+$ P1); b gel-type products fermented by kefir grains (K2), commercial mix of probiotic (P2) and kefir grains + commercial mix of probiotic $(\mathrm{K}+\mathrm{P} 2)$. Total Solids (TS). Different letters (a, b...) indicate statistically significant differences $(P<0.05)$ within fermented products for each formulation

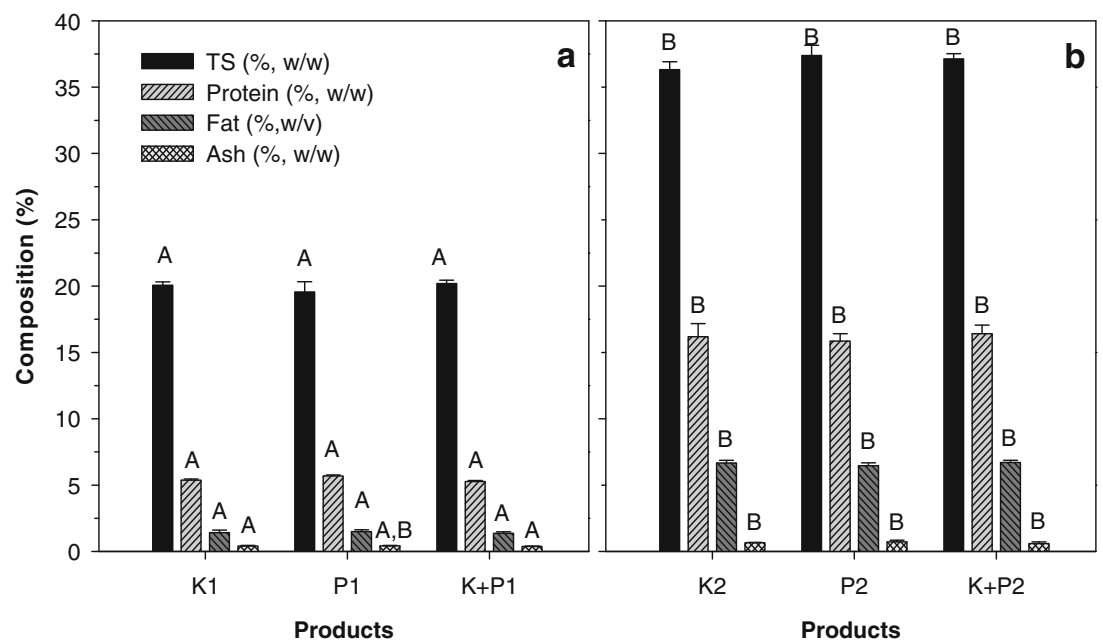




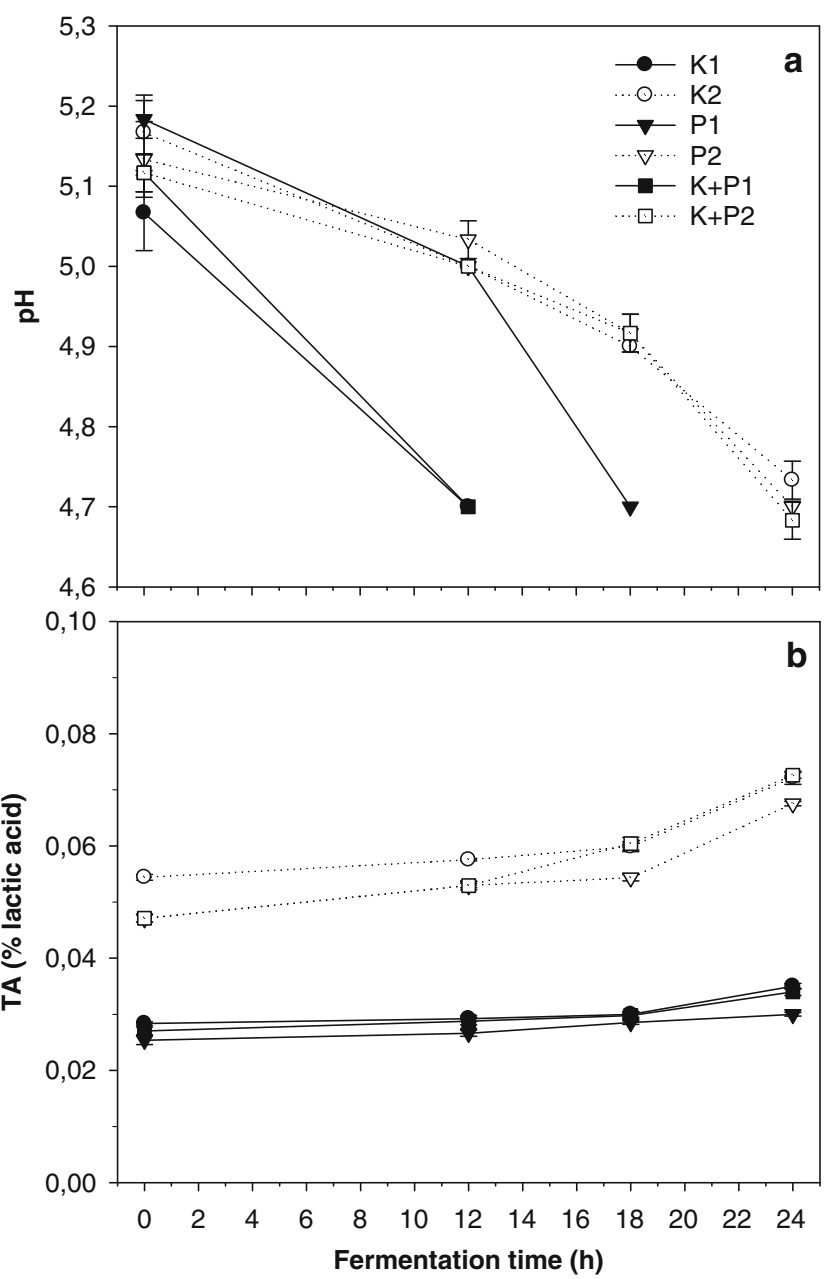

Fig. $2 \mathrm{pH}$ and titratable acidity (TA) over fermentation of liquid-type products fermented by kefir grains (K1), commercial mix of probiotic (P1) and kefir grains + commercial mix of probiotic $(\mathrm{K}+\mathrm{P} 1)$, and geltype products fermented by kefir grains (K2), commercial mix of probiotic $(\mathrm{P} 2)$ and kefir grains + commercial mix of probiotic $(\mathrm{K}+\mathrm{P} 2)$

processing of whey to produce the LWPC, associated with the rapid cooling of LWPC, would allow for lower levels of acidification before fermentation. However, acidification may be difficult to control in whey from the manufacture of raw milk cheese. During the storage period, a gradual $\mathrm{pH}$ decrease could be observed (with final values in the range of 4.44.6), while titratable acidity remained nearly constant between the first and the 21st day of storage. Again, gel-type products showed significantly higher acidity values. Lactic acid concentration in liquid-type products is similar to that reported by Magalhães et al. 2011, after $24 \mathrm{~h}$ incubation at $25^{\circ} \mathrm{C}$ of kefir grains in whey and deproteinized whey. According to these authors, significant levels of lactose consumption $(>50 \%)$ and ethanol (i.e., $0.8 \%$ ) and acetic acid production (i.e., $0.06 \%$ ) were observed only after $48 \mathrm{~h}$ of fermentation. After $24 \mathrm{~h}$ of fermentation, approximately $20 \%$ of the lactose had been consumed, whereas ethanol and lactic acid production

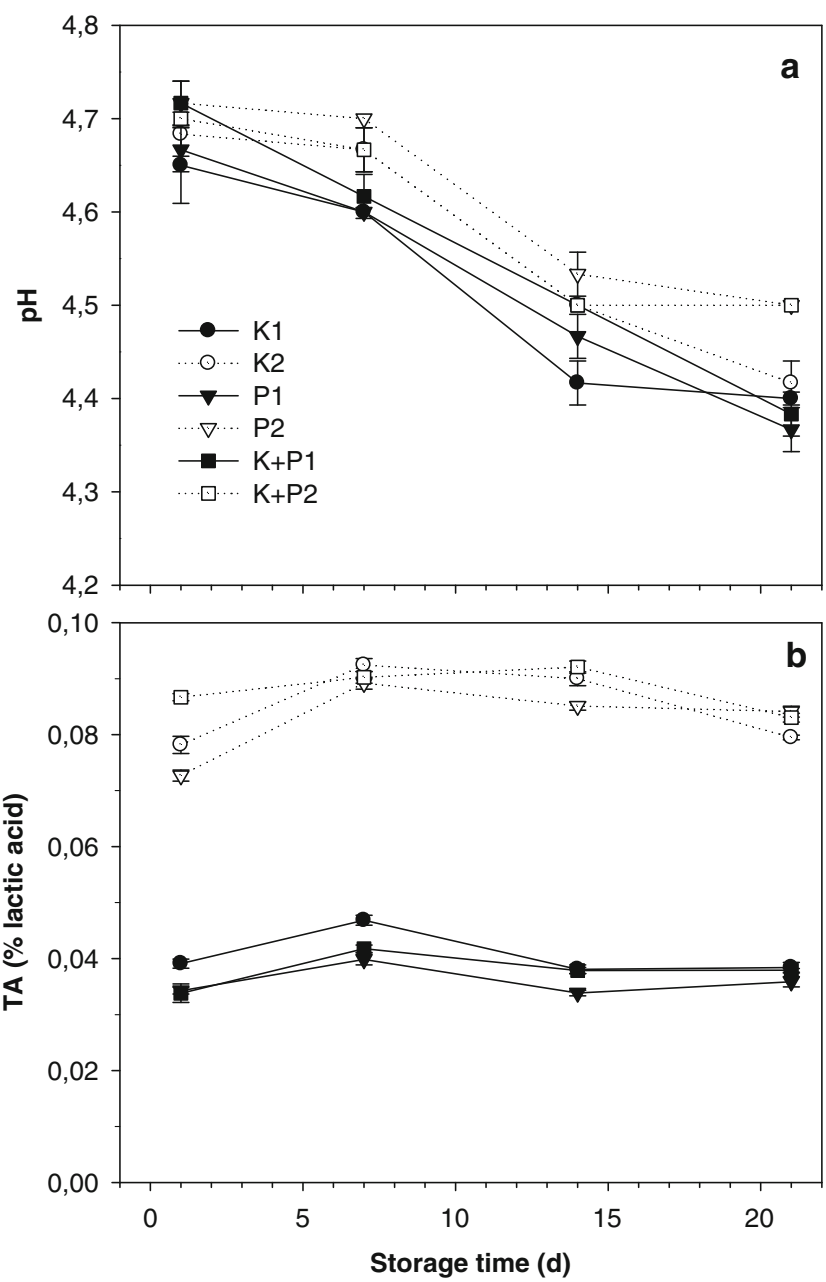

Fig. $3 \mathrm{pH}$ and titratable acidity (TA) over refrigerated storage of liquidtype products fermented by kefir grains (K1), commercial mix of probiotic ( $\mathrm{P} 1)$ and kefir grains + commercial mix of probiotic $(\mathrm{K}+\mathrm{P} 1)$, and gel type products fermented by kefir grains (K2), commercial mix of probiotic $(\mathrm{P} 2)$ and kefir grains + commercial mix of probiotic $(\mathrm{K}+\mathrm{P} 2)$

remained at 0.025 and $0.03 \%$, respectively. Nearly no acetic acid was produced. These aspects should deserve our attention in future work when addressing product sensory acceptance.

Figures 4 and 5 show the evolution of the rheological properties ( $G^{\prime}$ and $G$ ") of fermented products over refrigerated storage. In medium solids content products (Fig. 4), the viscous modulus (G”) was higher than the elastic modulus (G'), reflecting their liquid nature. The rheological properties of liquid-type products did not change significantly during the storage period. High solids content products (Fig. 5) showed gel-like characteristics $\left(G^{\prime}>G^{\prime}\right)$. The values for the elastic modulus of high solids products are similar to those reported by Dissanayake et al. (2010) for gels obtained from microparticulated whey proteins denatured by heat. In high solids content products containing kefir grains ( $\mathrm{K} 2$ and $\mathrm{K}+\mathrm{P} 2$ ), elastic (G') and viscous moduli (G”) significantly increased between the 14th and the $21 \mathrm{st}$ 

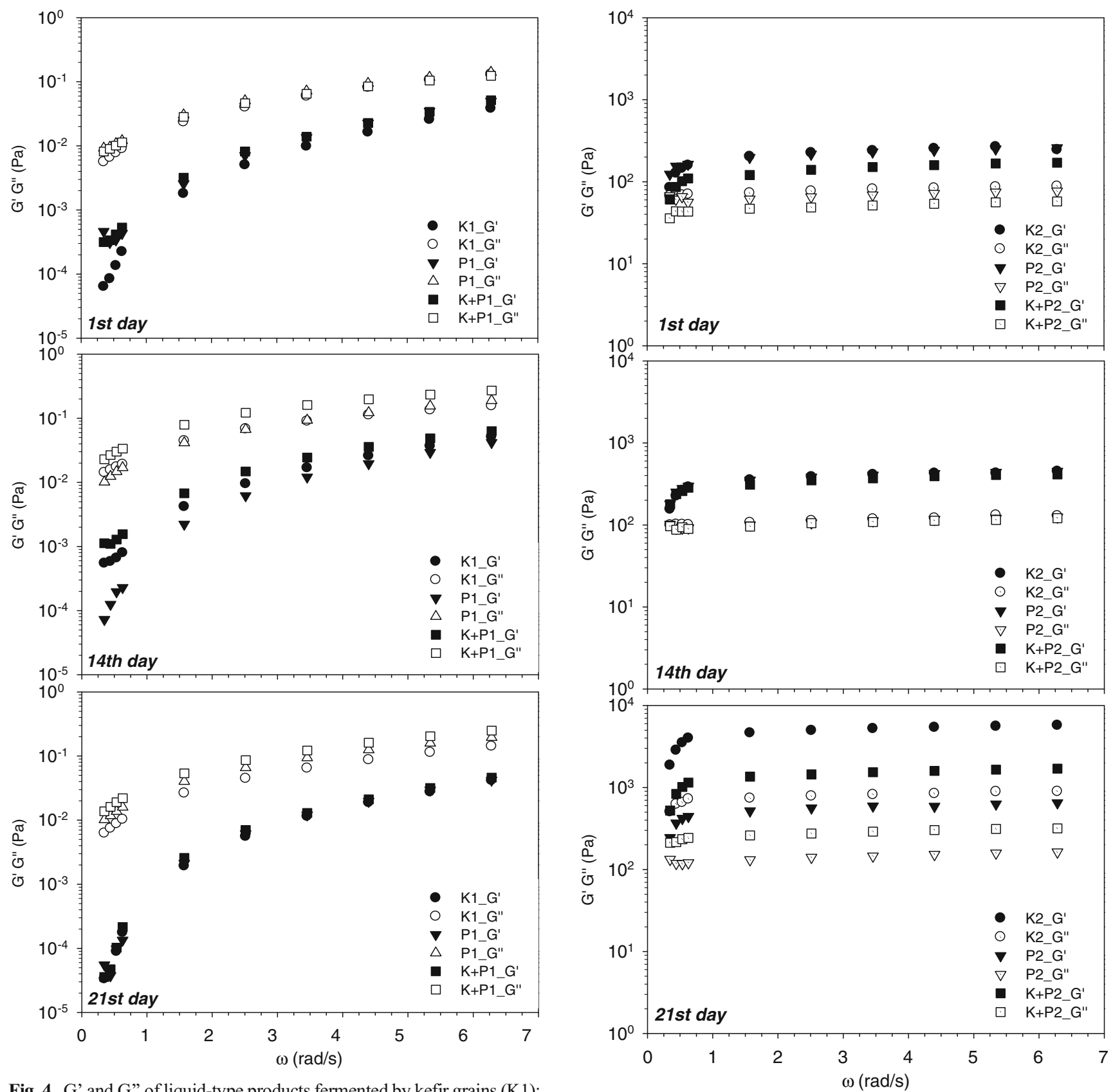

Fig. 4 G' and G" of liquid-type products fermented by kefir grains (K1); commercial mixture of probiotic bacteria $(\mathrm{P} 1)$; kefir grains + commercial mix of probiotic $(\mathrm{K}+\mathrm{P} 1)$, over refrigerated storage

days of storage. The dynamic viscosity of high solids products also showed a significant increase after the 14th day of storage (Fig. 6). After 14 days, high solids contents products presented a spongiform structure due to gas entrapment in the gel matrix, resulting in serum separation. This led to a significant increase in viscosity, with marked effects on product sensory acceptability.

Damping factor values $(\tan \delta)$ directly obtained from the $G " / G$ ' ratio can be used to clarify the viscoelastic behavior of a semi-solid food. If $\tan \delta$ values are lower than one, the elastic behavior predominates, whereas for

Fig. 5 G' and G" of gel-type products fermented by kefir grains (K2); commercial mixture of probiotic bacteria (P2); kefir grains + commercial mix of probiotic $(\mathrm{K}+\mathrm{P} 2)$, over refrigerated storage

$\tan \delta$ values higher than one a viscous behavior prevails. In the present study, $\tan \delta$ values at a frequency of $6.28 \mathrm{rads}^{-1}$ (data not shown) were higher than one for medium solids products $(2.41-5.39)$ and lower than one for high solids products $(0.16-0.37)$. These results indicate that the elastic nature in high solids products prevailed (gel state) over the viscous nature (liquid state), which is found in medium solids products. With storage, tan $\delta$ showed an increase in liquid-type fermented products and a decrease in gel-type fermented products. 


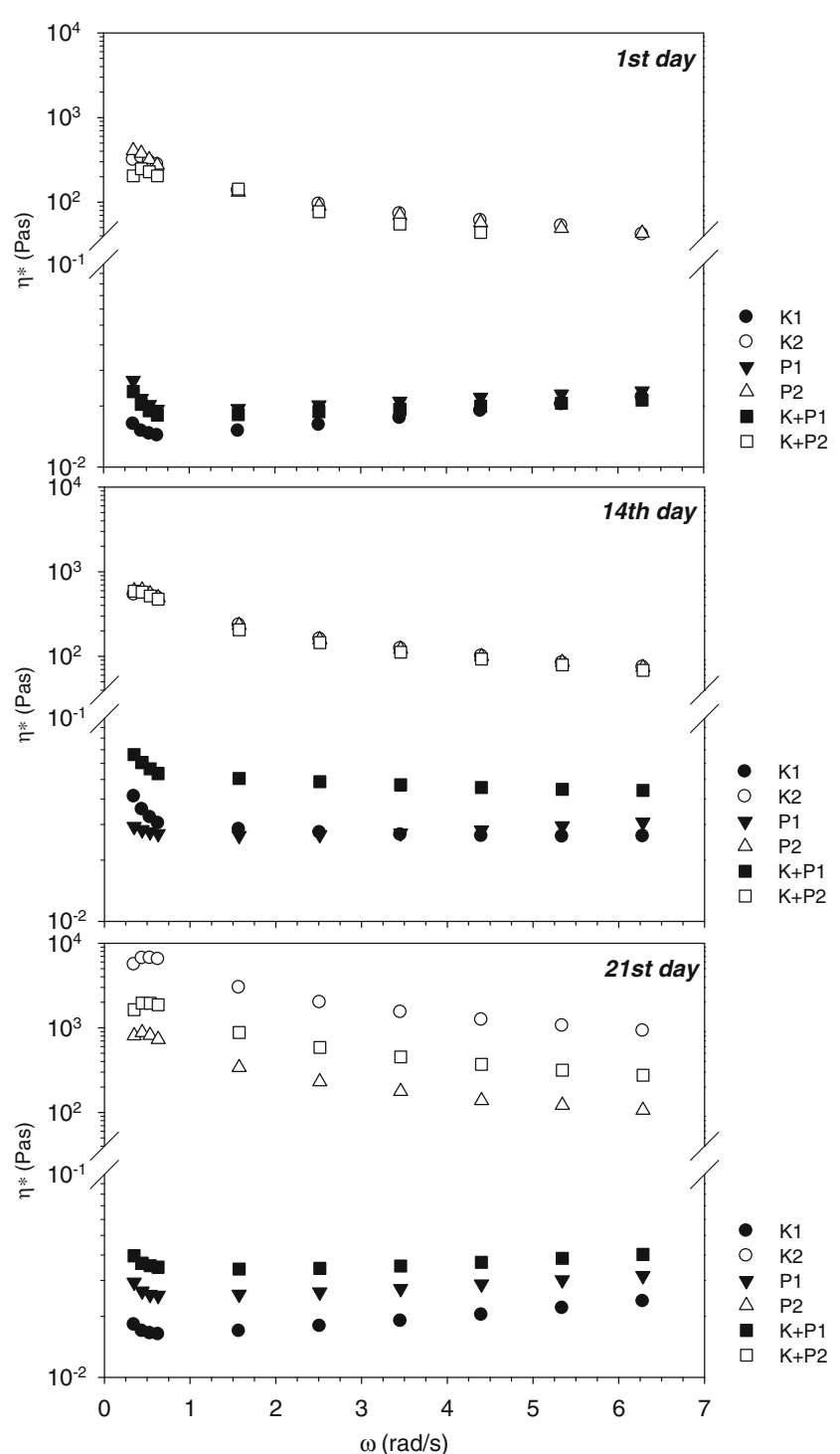

Fig. 6 Dynamic viscosity over refrigerated storage of liquid-type products fermented by kefir grains (K1), commercial mix of probiotic (P1) and kefir grains + commercial mix of probiotic $(\mathrm{K}+\mathrm{P} 1)$, and geltype products fermented by kefir grains (K2), commercial mix of probiotic $(\mathrm{P} 2)$ and kefir grains + commercial mix of probiotic $(\mathrm{K}+\mathrm{P} 2)$

\section{Microbiological profiles}

Generally, lactic acid bacteria predominate in kefir grains $(>8$ $\log _{10} \mathrm{CFU} \mathrm{mL} \mathrm{m}^{-1}$ ) and are more abundant than yeasts and acetic acid bacteria. However, fermentation conditions may affect this pattern (Farnworth 2005). The typical kefir organoleptic characteristics result from the metabolic activity of microorganisms, being lactic acid, acetaldehyde, ethanol, acetoin, diacetyl and carbon dioxide the main products of fermentation. Ethanol and $\mathrm{CO}_{2}$ provide the typical refreshing taste (Beshkova et al. 2003; Lopitz-Otsoa et al. 2006), while lactic acid provides the acidic and bitter flavor. Acetaldehyde accounts for the characteristic fermented milk flavor (Ertekin and Guzel-Seydim 2009).
The probiotic properties of microorganisms in kefir grains used in the present work have been reported elsewhere (Franco et al. 2013; Golowczyc et al. 2007; Bolla et al. 2011, 2013; Londero et al. 2012). Reported benefits are mainly related to the inhibition of pathogenic microorganisms and parasites. Other authors stress the importance of lactobacilli and yeast population stability over time, which is essential to ensure consistent product quality (Magalhães et al. 2010; Vardjan et al. 2013; Leite et al. 2013).

Adequate levels of presumptive lactococci, lactobacilli and yeasts (Fig. 7) were attained after the fermentation period (i.e., 6-7 $\log _{10} \mathrm{CFUmL}^{-1}$ ) and remained constant or showed an
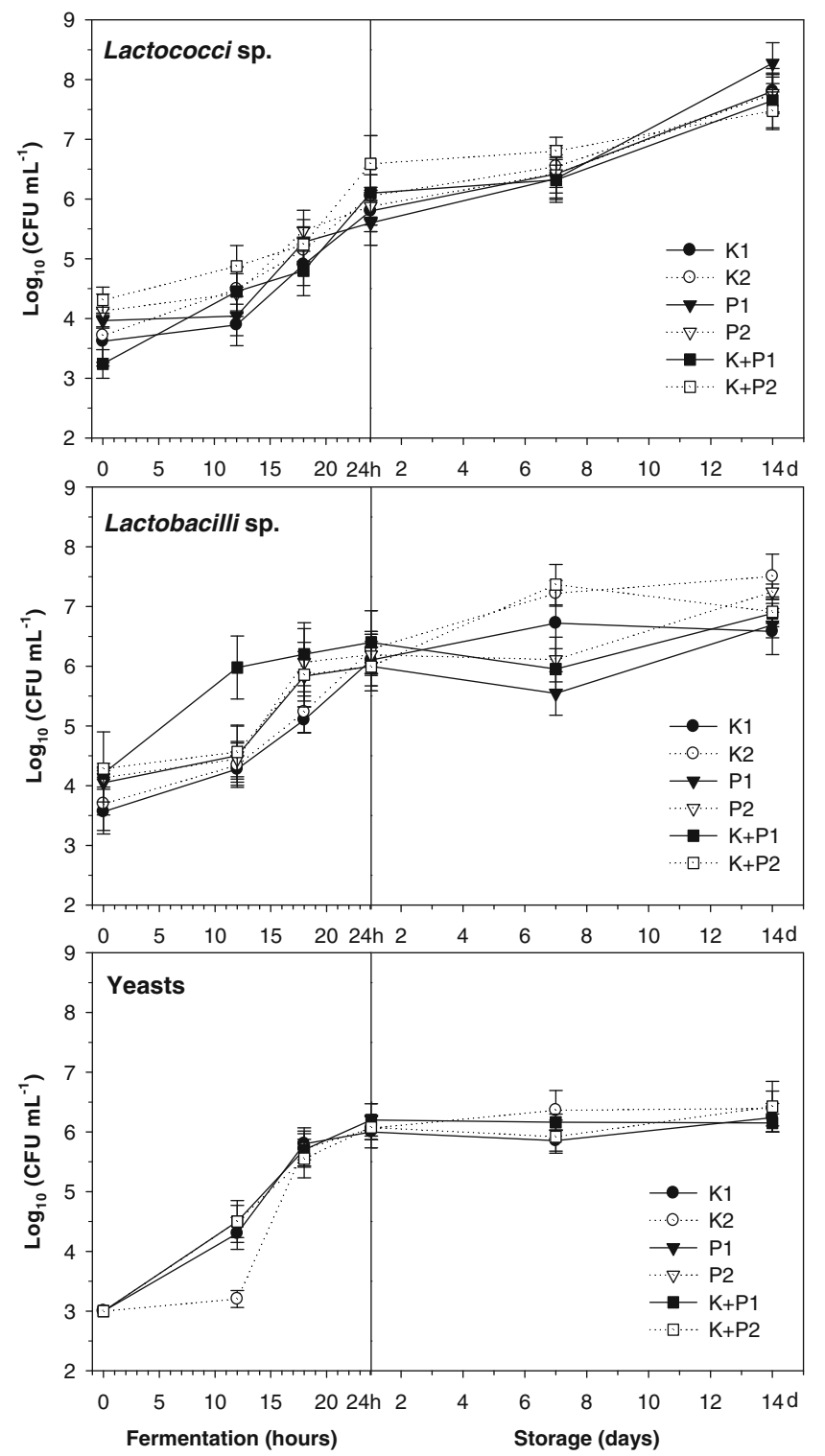

Fig. 7 Microbial counts $\left(\log _{10} \mathrm{CFUmL}^{-1}\right)$ over fermentation and refrigerated storage of liquid-type products fermented by kefir grains (K1), commercial mix of probiotic (P1) and kefir grains + commercial mix of probiotic $(\mathrm{K}+\mathrm{P} 1)$, and gel-type products fermented by kefir grains (K2), commercial mix of probiotic (P2) and kefir grains+ commercial mix of probiotic $(\mathrm{K}+\mathrm{P} 2)$ 
Fig. 8 Sensorial evaluation of liquid-type fermented products (K1, P1 and $\mathrm{K}+\mathrm{P} 1)$ and gel-type fermented products $(\mathrm{K} 2, \mathrm{P} 2$ and $\mathrm{K}+\mathrm{P} 2)$

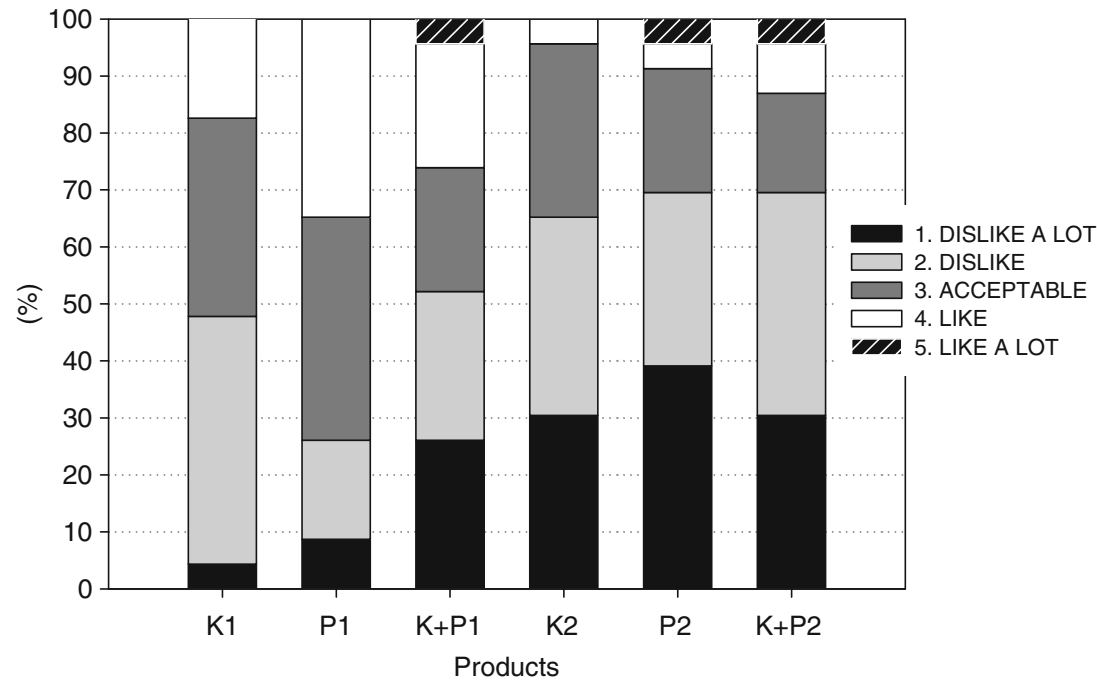

increase (for lactococci), until sensory evaluation (14 days). This demonstrates the resistance of such strains to storage conditions. As expected, products containing the mixture of probiotic bacteria alone had no yeast counts. It has been widely reported that at least 6-7 $\log _{10} \mathrm{CFUg}^{-1}$ of viable probiotic microorganisms are required in a food product claiming probiotic properties (Tripathi and Giri 2014; Hill et al. 2014). Taking into account the high microbial counts in the products as well as their maintenance over storage, it can be concluded that the use of fresh kefir grains and/or commercial probiotics as an inoculate in LWPC seems to be an excellent choice for the production of novel functional ovine fermented products.

\section{Sensorial analyses}

Liquid-type fermented products were better accepted than geltype fermented products (Fig. 8). The most accepted product was P1, but almost $30 \%$ of the consumers still considered it unacceptable. Solid products were poorly rated, with more than $60 \%$ of consumers considering them unacceptable. The main flaws attributed to solid products were an intense acidic taste, poor texture associated to phase separation, and ovine cheese flavor, which does not appropriately match the flavor of fruit pulp. Texture flaws can be eliminated if total solid level is lowered to $20-25 \%$ to keep the products liquid. Concerning taste problems, several consumers referred that they would prefer the product without adding fruit pulp. These aspects should be taken into consideration in the development of new formulations.

\section{Conclusion}

Although further investigation is needed to improve the organoleptic properties of the formulations, concentration of ovine cheese whey by UF and thermal concentrate denaturation provides a good basis for the production of innovative fermented dairy products. This technology allows for a direct valorization of ovine whey in small-scale plants with advantages to the production of whey cheese (Requeijão). The main advantages are a potential higher yield and a longer product shelf life. Furthermore, the solution proposed may also be attractive for producers as a way to reach the niche market of healthy dairy products.

Acknowledgments This work was supported by CERNAS - Research Center for Natural Resources, Environment and Society and the CYTED Program (115RT0488). We also acknowledge Queijaria Flôr da Beira for providing ovine whey.

\section{References}

Abraham A, Gómez-Zavaglia A, Garrote G, Brandi LI, De Antoni GL, Fausto R (2011) Fermented product based on milk whey permeate: production processes and uses. Int Patent WO 2011005128 A2

Amatayakul T, Sherka T, Shah NP (2006) Syneresis in set yogurt as affected by EPS starter cultures and levels of solids. Int J Dairy Technol 59:216-221

Antunes AC, Cazetto TF, Bolini HLA (2005) Viability of probiotic micro-organisms during storage, postacidification and sensory analysis of fat-free yogurts with added whey protein concentrate. Int J Dairy Technol 58:169-173

AOAC - Association of Official Analytical Chemists (1997). Dairy Products In: Official methods of analysis, Volume II, 16th (edn.), Arlington

Athanasiadis I, Paraskevopoulou A, Blekas G, Kiosseoglou V (2004) Development of a novel whey beverage by fermentation with kefir granules. Effect of various treatments. Biotechnol Prog 20:10911095

Beshkova DM, Simova ED, Frengova GI, Simov ZI, Dimitrov ZP (2003) Production of volatile aroma compounds by kefir starter cultures. Int Dairy J 13:529-535

Bolla PA, Serradell ML, de Urraza PJ, De Antoni GL (2011) Effect of freeze-drying on viability and in vitro probiotic properties of a 
mixture of lactic acid bacteria and yeasts isolated from kefir. J Dairy Res 78:15-22

Bolla PA, Carasi P, Serradell Mde L, De Antoni GL (2013) Kefir-isolated Lactococcus lactis subsp. Lactis inhibits the cytotoxic effect of clostridium difficile in vitro. J Dairy Res 80(1):96-102

Chung C, Degner B, McClements DJ (2013) Development of reducedcalorie foods: microparticulated whey proteins as fat mimetics in semi-solid food emulsions. Food Res Int 56:136-145

Di Cagno R, Pasquale I, De Angelis M, Buchin S, Rizzello CG, Gobbetti M (2014) Use of microparticulated whey protein concentrate, exopolysaccharide-producing streptococcus thermophilus, and adjunct cultures for making low-fat Italian caciotta-type cheese. J Dairy Sci 97:72-84

Díaz O, Pereira CD, Cobos A (2009) Applications of whey protein concentrates and isolates from the food industry. Alimentaria Investig Tecnol Seguridad 400:108-115

Dissanayake M, Kelly AL, Vasiljevic T (2010) Gelling properties of microparticulated whey proteins. J Agric Food Chem 58:6825-6832

Ertekin B, Guzel-Seydim ZB (2009) Effect of fat replacer on kefir quality. J Sci Food Agric 90:543-548

Farnworth ER (2005) Kefir-a complex probiotic. Food Sci Technol Bull Funct Foods 2:1-17

Franco MC, Golowczyc MA, De Antoni GL, Pérez PF, Humen M, Serradell MLA (2013) Administration of kefir-fermented milk protects mice against giardia intestinalis infection. J Med Microbiol 62: $1815-1822$

Gerosa S, Skoet J (2012) Milk availability - trends in production and demand and medium-term outlook. ESA Working paper No. 1201 . Food and agriculture organization of the United Nations. www.fao.org/economic/esa

Golowczyc MA, Mobili P, Garrote GL, Abraham AG, De Antoni GL (2007) Protective action of lactobacillus kefir carrying S-layer protein against salmonella enterica serovar enteritidis. Int J Food Microbiol 118:264-273

Henriques MHF, Gomes DMGS, Rodrigues D, Pereira CJD, Gil MHM (2011) Performance of bovine and ovine liquid whey protein concentrate on functional properties of set yoghurts. Procedia Food Sci 1:2007-2014

Henriques MHF, Gomes DMGS, Pereira CJD, Gil MHM (2013) Effects of liquid whey protein concentrate on functional and sensorial properties of set yogurts and fresh cheese. Food Bioproc Technol 6:1-12

Hill C, Guarner F, Reid G, Gibson GR, Merenstein DJ, Pot B, Morelli L, Berni Canani R, Flint HJ, Salminen S, Calder PC, Sanders ME (2014) Expert consensus document: the international scientific association for probiotics and prebiotics consensus statement on the scope and appropriate use of the term probiotic. Nat Rev Gastroenterol Hepatol 11:506-514

IPQ - Instituto Português da Qualidade (1990) Leite e produtos lácteos. Edição Normas Portuguesas, Lisboa, Portugal

Leite AMO, Leite DC, Del Aguila EM, Alvares TS, Peixoto RS, Miguel MAL, Silva JT, Paschoalin VMF (2013) Microbiological and chemical characteristics of Brazilian kefir during fermentation and storage processes. J Dairy Sci 96:4149-4159

Londero A, Hamet MF, De Antoni GL, Garrote GL, Abraham AG (2012) Kefir grains as a starter for whey fermentation at different temperatures: chemical and microbiological characterization. J Dairy Res 79:262-271

Lopitz-Otsoa F, Rementeria A, Elguezabal N, Garaizar J (2006) Kefir: a symbiotic yeasts-bacteria community with alleged healthy capabilities. Rev Iberoam Micol 23:67-74
Madureira AR, Pereira CI, Truszkowskab K, Gomes AM, Pintado ME, Malcata FX (2005) Survival of probiotic bacteria in a whey cheese vector submitted to environmental conditions prevailing in the gastrointestinal tract. Int Dairy J 15:921-927

Madureira AR, Amorim M, Gomes AM, Pintado ME, Malcata FX (2011) Protective effect of whey cheese matrix on probiotic strains exposed to simulated gastrointestinal conditions. Food Res Int 44(1):465470

Madureira AR, Soares JC, Pintado ME, Gomes AMP, Freitas AC, Malcata FX (2015) Effect of the incorporation of salted additives on probiotic whey cheeses. Food Biosci 10:8-17

Magalhães KT, Pereira MA, Nicolau A, Dragone G, Domingues L, Teixeira JA, Silva JB A e, Schwan RF (2010) Production of fermented cheese whey-based beverage using kefir grains as starter culture: evaluation of morphological and microbial variations. Bioresour Technol 101:8843-8850

Magalhães KT, Dragone G, de Melo Pereira G, Oliveira JM, Domingues L, Teixeira JA, Silva JB A e, Schwan RF (2011) Comparative study of the biochemical changes and volatile compound formations during the production of novel whey-based kefir beverages and traditional milk kefir. Food Chem 126:249-253

Nicolai T, Britten M, Schmitt C (2011) $\beta$-lactoglobulin and WPI aggregates: formation, structure and applications. Food Hydrocoll 25: 1945-1962

NP4146 (1991) Leite e produtos lácteos. Métodos de colheita de amostras. Comissão Técnica - 32, $1^{\text {a }}$ edição, Portugal

Pescuma M, Hebert EM, Mozzi F, Font de Valdez G (2010) Functional fermented whey-based beverage using lactic acid bacteria. Int $\mathrm{J}$ Food Microbiol 141:73-81

Pintado ME, Macedo AC, Malcata FX (2001) Review: technology, chemistry and microbiology of whey cheeses. Food Sci Technol Int 7:105-116

Sandoval-Castilla O, Lobato-Caballeros C, Aguirre-Mandujano E, Vernon-Carter E (2004) Microstructure and texture of yogurt as influenced by fat replacers. Int Dairy J 14:151-159

Smithers GW (2008) Whey and whey proteins - from 'gutter-to-gold'. Int Dairy J 18:695-704

Sodini I, Montella J, Tong PS (2005) Physical properties of yogurt fortified with various commercial whey protein concentrates. J Sci Food Agric 85:853-859

Sodini I, Mattas J, Tong PS (2006) Influence of $\mathrm{pH}$ and heat treatment of whey on the functional properties of whey protein concentrates in yoghurt. Int Dairy J 16:1464-1469

Torres IC, Janhøj T, Mikkelsen BØ, Ipsen R (2011) Effect of microparticulated whey protein with varying content of denatured protein on the rheological and sensory characteristics of low-fat yoghurt. Int Dairy J 21:645-655

Torres IC, Rubio JMA, Ipsen R (2012) Using fractal image analysis to characterize microstructure of low-fat stirred yoghurt manufactured with microparticulated whey protein. J Food Eng 109:721-729

Tripathi MK, Giri SK (2014) Probiotic functional foods: survival of probiotics during processing and storage. J Funct Foods 9:225-241

Vardjan T, Lorbeg PM, Rogelj I, Čanžek Majhenič A (2013) Characterization and stability of lactobacilli and yeast microbiota in kefir grains. J Dairy Sci 96:2729-2736

Wang W, Bao Y, Hendricks GM, Guo M (2012) Consistency, microstructure and probiotic survivability of goats' milk yoghurt using polymerized whey protein as a co-thickening agent. Int Dairy J 24:113-11 